\title{
Cadmium toxicity and zinc limitation in centric diatoms of the genus Thalassiosira
}

\author{
Philippe D. Tortell ${ }^{*}$, Neil M. Price \\ Department of Biology, McGill University, 1205 Ave. Dr. Penfield, Montréal, Québec, Canada H3A 1B1
}

\begin{abstract}
Cadmium toxicity and Zn limitation were examined in centric diatoms to test the hypothesis that resistance to high concentrations of toxic metals was related to the assimilation of essential ones. Nine species of the genus Thalassiosira were cultured in artificial seawater media under $\mathrm{Zn}$ deficiency and in trace-metal-replete media with $\mathrm{Cd}$ additions ranging from $10 \mathrm{nM}$ to $10 \mu \mathrm{M}$. Cadmium sensitivity, measured as $\left[\mathrm{Cd}^{2+}\right]$ required to inhibit growth by $50 \%\left(\mathrm{pCd}^{50}\right)$, varied significantly among species $(\mathrm{p}<0.001)$. Clones isolated from offshore oligotrophic environments were significantly more resistant to $\mathrm{Cd}$ toxicity and $\mathrm{Zn}$ deficiency than those indigenous to coastal regions $(p<0.01)$. Differences in $\mathrm{Cd}$ resistance could not be explained by cellular exclusion since all species accumulated remarkably similar amounts of $\mathrm{Cd}(\mathrm{Cd}$ quota $~ 30 \mu \mathrm{mol} \mathrm{Cd}: \mathrm{mol} \mathrm{C})$ at the highest concentrations tested. $\mathrm{pCd}^{50} \mathrm{~s}$ were positively correlated to $\mathrm{QCd^{50 }} \mathrm{s}(\mathrm{Cd}$ quotas required to inhibit growth by $50 \%$ ). Tolerance of the diatoms to intra- and extracellular $\mathrm{Cd}$ was positively correlated to their growth rates under $\mathrm{Zn}$ limiting conditions so that species most resistant to $\mathrm{Cd}$ toxicity were those least affected by $\mathrm{Zn}$ limitation. Cadmium concentrations that were not toxic under trace-metal-saturating conditions inhibited growth rate of $\mathrm{Zn}$-limited $T$. weissflogii cultures by approximately $70 \%$, but had no effect on Felimited cultures. The results thus suggest that $C d$ toxicity is mediated in part through the impairment of $\mathrm{Zn}$ assimilation in diatoms.
\end{abstract}

KEY WORDS: Cadmium - Zinc - Deficiency - Toxicity - Phytoplankton - Trace metals - Diatoms

\section{INTRODUCTION}

Total dissolved concentrations of trace metals decrease by 3 to 4 orders of magnitude between coastal and oceanic waters, from micro- to nano- and picomolar levels. This chemical gradient exists for both essential and non-essential metals and has apparently imposed significant constraints on the biota. In some offshore habitats, for example, concentrations of Fe are so low that they limit phytoplankton productivity and favour growth of small-sized autotrophs (Price et al. 1991, 1994, Martin et al. 1994). Unbalanced supply of metals relative to cellular demands in upwelling environments can also contribute to metal deficiency through competitive interactions (Sunda et al, 1981). Phytoplankton have undoubtedly adapted to counter-

\footnotetext{
- Present address: Department of Ecology and Evolutionary Biology, Princeton University, New Jersey 08544-1003, USA. E-mail: ptortell@phoenix.princeton.edu
}

act these stresses and to minimize their impact by processes that have been shaped by natural selection during the course of their evolution.

One of the most discriminating features of oceanic and coastal phytoplankton concerns their ability to grow under metal-deficient conditions. All species that have been isolated from offshore waters have considerably lower trace metal requirements than closely related neritic species (Ryther \& Kramer 1961, Brand et al. 1983, Sunda et al, 1991, M.T. Maldonado \& N. M. Price unpubl.). As a result, oceanic isolates can maintain near maximal rates of growth in metal-poor medium while coastal isolates are barely able to reproduce. These dramatically different responses persist even after decades of growth of the isolates in highly metalenriched media. Low metal concentrations thus appear to have influenced the evolution of phytoplankton in the open ocean and are presently affecting their ecology.

The impact of high concentrations of metals on the coastal phytoplankton community has been more diffi- 
cult to detect. Production of metal-detoxifying phytochelatins by nearshore assemblages implies that phytoplankton are experiencing some sort of metal stress (Ahner et al. 1994). Metal-tolerant strains of phytoplankton have also been isolated from habitats impacted by point source pollution. (Jensen et al. 1974), but these are exceptional cases. Pervasive low-level enrichment of potentially toxic metals more commonly occurs from rivers and sediments, contributing to higher concentrations inshore (Martin \& Whitfield 1983). Brand et al. (1986) recognized the existence of this oceanic gradient, and hypothesized that coastal species would have developed greater resistance to toxic metals (because they have been constantly exposed to them) than oceanic species living in comparatively pristine environments. The results of their experiments, however, did not support the predicted habitat-related pattern in $\mathrm{Cd}$ sensitivity of phytoplankton.

Given our present understanding of metal interactions in phytoplankton (Sunda 1988/89, Price \& Morel 1994), we have reexamined the issue of habitat-related patterns of toxicity resistance. Cadmium, one of the most toxic elements (Davies 1978), is highly concentrated in coastal waters relative to the open sea (Bruland 1980, 1992, Bruland \& Franks 1983). It is known to substitute for $\mathrm{Zn}$ and promote growth of $\mathrm{Zn}$ limited phytoplankton (Price \& Morel 1990) and to interfere with $\mathrm{Mn}$ and Fe assimilation at very high concentrations (Hart et al. 1979, Foster \& Morel 1982, Harrison \& Morel 1983). If $\mathrm{Cd}$ exerts its toxic effects by interfering with the utilization of essential metals, then those species that are most tolerant of essential metal deficiency or that require very small amounts of these elements for growth may be more immune to its effects.

In the present study, we tested the hypothesis that oceanic phytoplankton with low metal requirements would be more resistant to toxic metals than coastal species by examining the relationship between $\mathrm{Cd}$ toxicity and $\mathrm{Zn}$ deficiency. Nine species of Thalassiosira from a variety of ocean habitats were grown in media containing a range of $\mathrm{Cd}$ ion concentrations, and intracellular $\mathrm{Cd}$ quotas and growth rates were measured. Experiments were also conducted to elucidate the importance of $\mathrm{Cd}$ and essential metal antagonisms in one of the test species

\section{MATERIAL AND METHODS}

Study organisms. All algal clones, centric diatoms of the genus Thalassiosira, were obtained from the Center for Culture of Marine Phytoplankton, Bigelow Laboratory for Ocean Sciences, West Boothbay Harbor, Maine, USA. Clones were isolated from a variety of marine habitats, including eutrophic estuarine waters, oligotrophic oceanic gyres, and coastal and offshore upwelling areas, and ranged in volume from $40 \mathrm{fl}(1 \mathrm{fl}$ $\left.=10^{-15} \mathrm{l}\right)(\mathrm{T}$. pseudonana, clone $3 \mathrm{H})$ to $877 \mathrm{fl}(\mathrm{T}$. decipiens, clone 983) (Table 1). Cultures were maintained at $20^{\circ} \mathrm{C}$ under continuous saturating light $\left(150 \mu \mathrm{E} \mathrm{m} \mathrm{m}^{-2}\right.$ $\left.\mathrm{s}^{-1}\right)$. Although sterile techniques were used throughout the experiments, not all cultures were axenic. Coulter Counter measurements (see 'Experimental measurements'), however, revealed that bacterial biovolume was small relative to that of phytoplankton and that most bacteria were removed during filtration of samples prior to analysis

Culture media. Basal culture medium, consisting of synthetic ocean water (SOW) and major nutrient solutions, was prepared, chelexed, and sterilized as described by Price et al. (1988/89). Sterile medium was transferred into acid-washed, autoclaved polycarbonate bottles to which filter-sterilized $(0.2 \mu \mathrm{m}$ Acrodisc filters) trace-metal-stock solutions and $f / 2$ vitamins were subsequent].y added.

Table 1. Thalassiosira spp. Clonal designations, collection sites, and habitat classification. Cell volumes are those of control cultures grown in metal-replete medium lacking added $\mathrm{Cd}$

\begin{tabular}{|c|c|c|c|}
\hline Species & Habitat & Collection site & ell volume (fl) \\
\hline $\begin{array}{l}\text { Thalassiosira oceanica } \\
\text { clone 13-1 }\end{array}$ & Oceanic & $\begin{array}{l}\text { Sargasso Sea } \\
33^{\circ} 11^{\prime} \mathrm{N}, 65^{\circ} 15^{\prime} \mathrm{W}\end{array}$ & 103 \\
\hline $\begin{array}{l}\text { Thalassiosira oceanica } \\
\text { clone } 1003\end{array}$ & Oceanic & $\begin{array}{l}\text { Sargasso Sea } \\
36^{\circ} 11^{\prime} \mathrm{N}, 69^{\circ} 35^{\prime} \mathrm{W}\end{array}$ & 102 \\
\hline $\begin{array}{l}\text { Thalassiosira parthenaia } \\
\text { clone Thal } 9\end{array}$ & Oceanic & $\begin{array}{l}\text { Equatorial Pacific } \\
0^{\circ} 02^{\prime} \mathrm{N}, 139^{\circ} 59^{\circ} \mathrm{W}\end{array}$ & 116 \\
\hline $\begin{array}{l}\text { Thalassiosira pseudonana } \\
\text { clone } 1014\end{array}$ & Oceanic & $\begin{array}{l}\text { North Pacific Gyre } \\
28^{\circ} \mathrm{N}, 155^{\circ} \mathrm{W}\end{array}$ & 52 \\
\hline $\begin{array}{l}\text { Thalassiosira subtilis } \\
\text { clone 50ait }\end{array}$ & Oceanic & $\begin{array}{l}\text { Equatorial Pacific } \\
0^{\circ} 02^{\prime} \mathrm{N}, 139^{\circ} 59^{\prime} \mathrm{W}\end{array}$ & 840 \\
\hline $\begin{array}{l}\text { Thalassiosira decipiens } \\
\text { clone } 983\end{array}$ & Coastal & $\begin{array}{l}\text { Magdalena Bay, Baja } \\
\text { California } \\
25^{\circ} \mathrm{N}, 112^{\circ} \mathrm{W}\end{array}$ & 877 \\
\hline $\begin{array}{l}\text { Thalassiosira pseudonana } \\
\text { clone } 3 \mathrm{H}\end{array}$ & Coastal & $\begin{array}{l}\text { Moriches Bay, Forge } \\
\text { River, Long Island, NY } \\
39^{\circ} 10^{\prime} N, 72^{\circ} 45^{\prime} \mathrm{W}\end{array}$ & Y \\
\hline $\begin{array}{l}\text { Thalassiosira rotula } \\
\text { clone } 1016\end{array}$ & Coastal & $\begin{array}{l}\text { Peru Upwelling } \\
10^{\circ} \mathrm{S}, 78^{\circ} \mathrm{W}\end{array}$ & 75 \\
\hline $\begin{array}{l}\text { Thalassiosira weissflogii } \\
\text { clone Actin }\end{array}$ & Coastal & $\begin{array}{l}\text { Gardiner's Island, } \\
\text { Long Island, NY } \\
41^{\circ} 05^{\prime} \mathrm{N}, 72^{\circ} 06^{\prime} \mathrm{W}\end{array}$ & 660 \\
\hline
\end{tabular}


Concentrations of trace metals in the media for $\mathrm{Cd}$ toxicity experiments were the same as those used by Brand et al. (1986) with $100 \mu \mathrm{M}$ nitrilotriacetic acid (NTA) as a chelating agent, yielding the following free ion concentrations $(-\log$ free metal ion concentration $=$ pMetal): pFe 19.29, pMn 7.53, pCu 12.25, pZn 9.04, pCo 10.05, pSe 10.57, pMo 7.00. Various amounts of $\mathrm{CdCl}_{2}$ were added to achieve a range in final concentration from $10^{-8}$ to $10^{-5} \mathrm{M}$ corresponding to $\mathrm{pCd}$ values of: $9.85,9.37,8.85,8.37,7.85,7.37,6.85$. Calculation of free metal ion concentrations, performed using the chemical equilibrium program MINEQL (Westall et al. 1976), showed that the addition of Cd did not appreciably affect the speciation of other metals in the media. Because $\mathrm{Cd}$ is not as ubiquitous a contaminant as $\mathrm{Fe}, \mathrm{Zn}$, and $\mathrm{Cu}$, a background level of $<1 \mathrm{nM} \mathrm{Cd}$ (an order of magnitude less than our lowest experimental addition) was assumed in control (no added Cd) media. For Zn-deficient medium, concentrations of $\mathrm{Fe}, \mathrm{Mn}$, $\mathrm{Cu}, \mathrm{Co}$, Se, and Mo were those given by Price et al. (1988/89) using $100 \mu \mathrm{M}$ EDTA, with $\mathrm{Zn}^{2+}$ concentration set at $10^{-12.5} \mathrm{M}(\mathrm{pZn}=12.5$, total $[\mathrm{Zn}]=6.26 \mathrm{nM})$. Preparation and manipulation of all trace metal solutions were performed in a laminar flow hood using sterile and trace metal clean techniques (Price et al. 1988/89). All media were allowed to equilibrate chemically for at least $12 \mathrm{~h}$ before use.

Determination of growth rates. Cultures were maintained in acid-washed $28 \mathrm{ml}$ polycarbonate tubes using the semi-continuous batch culture method described by Brand et al. (1981). Culture tubes were sterilized by microwaving (Keller et al. 1988). In vivo chlorophyll a fluorescence of the cultures was measured at least daily with a model 10-AU Turner Designs fluorometer, and growth rates were determined from the slopes of least-squares regressions of logarithmically transformed fluorescence data plotted against time. Acclimation was assumed to be complete when cells had completed a minimum of 10 doublings in the experimental medium and the coefficient of variation of growth rates in successive transfers was less than $10 \%$. Relative growth rates were calculated by dividing the measured growth rates $(\mu)$ by the maximum growth rates $\left(\mu_{\max }\right)$ determined in metal-replete control media, lacking added $\mathrm{Cd}$. Species' relative growth rates in $\mathrm{Zn}$ deficient medium (pZn 12.5) were used as a measure of their ability to tolerate $\mathrm{Zn}$ limitation.

Experimental measurements. Acclimated cultures were inoculated in triplicate, and growth of all replicates was monitored. Inoculations were made in a sterile, trace-metal clean room equipped with a positively pressurized, filtered (High Efficiency Particulate Air filter, $0.3 \mu \mathrm{m}$ ) air system. Elemental $\mathrm{C}$ was measured in mid-exponential phase cultures grown in the absence of added $\mathrm{Cd}$, by collecting $25 \mathrm{ml}$ onto pre- combusted Whatman GF/C filters ( 4 h at $425^{\circ} \mathrm{C}$ ). Samples were analyzed with a Carlo Erba elemental analyzer. Cell volumes and densities were also determined in these cultures using a Coulter Counter (model $\mathrm{Z}_{256}$ ) that was calibrated with $5 \mu \mathrm{m}$ diameter latex beads. Volume-normalized carbon cell quotas ( $\mathrm{QC}^{\mathrm{vol}}$ ) were calculated for each species from C cell ${ }^{-1}$ (pmol cell-1) and cell volume ( $\mathrm{fl} \mathrm{cell}{ }^{-1}$ ) measurements. These quotas were used to calculate $C$ cell $^{-1}$ in the $C d$-treated cells from cell volume measurements in mid-exponential phase cultures. Preliminary experiments showed that despite significant changes in cell volume under $\mathrm{Cd}$ stress, $\mathrm{QC}^{\mathrm{vol}}$ in Thalassiosira weissflogii was unaffected (C. D. Payne \& N. M. Price unpubl.). The same was assumed to be true for all species.

Intracellular $\mathrm{Cd}$ concentrations were measured by growing cells in media containing various amounts of carrier-free $\mathrm{Cd}^{109}$ (Amersham, UK, $11.7 \mathrm{mCi} \mathrm{mol}^{-1}$ ). Carrier-free additions permitted high specific activities to be obtained with negligible changes in the total $\mathrm{Cd}$ concentration in test media. Cultures were inoculated at low densities (approximately 100 cells $\mathrm{ml}^{-1}$ ) and allowed to complete at least 8 divisions before harvesting to ensure uniform labelling of cellular material. Cells of mid-exponential phase cultures were collected by filtering $25 \mathrm{ml}$ onto 1 or $3 \mu \mathrm{m}$ Poretics polycarbonate membrane filters. Before running dry, the cells were rinsed with $10 \mathrm{ml}$ of $1 \mathrm{mM}$ diethyltriaminepentaacetic acid (DTPA) dissolved in SOW to remove any $\mathrm{Cd}$ loosely adsorbed to the cell surface (Lee \& Morel 1995). This solution was allowed to stand in the filtration apparatus for $10 \mathrm{~min}$ before being drained to near dryness and then rinsed with $10 \mathrm{ml}$ of SOW. Samples were preserved with Lugol's solution for subsequent cell counts by microscopy in a Palmer-Maloney settling chamber. Replicate counts of at least 250 cells were made for each sample. The radioactivity on the filters was measured by liquid scintillation counting on an LKB scintillation counter with Ecolyte fluor (ICN). Ali data were corrected for filter adsorption of $\mathrm{Cd}^{109}$ by filtering an equivalent volume of labelled test media and subtracting the activity retained on the filters. Cadmium cell quotas $\left(Q_{C d}\right.$, amol cell $\left.{ }^{-1}\right)$ were normalized to cellular $C$ to eliminate interspecific variability in cell volumes and $Q_{C}{ }^{\text {vol }}$.

Intracellular $\mathrm{Cd}$ concentrations and cell volumes were not measured for 3 of the species: Thalassiosira parthenaia, $T$. rotula, and $T$. decipiens. The latter 2 were only grown in the 4 highest experimental $\mathrm{Cd}$ concentrations.

Data analysis. Two indices of metal toxicity similar to those used in previous studies (Gavis et al. 1981, Fisher et al. 1984, Brand et al. 1986) were calculated from the growth data to compare the Cd sensitivity of the species. A least-squares, linear regression equation 
describing the declining portion of each growth curve was used to estimate the greatest $\mathrm{Cd}^{2+}$ concentration allowing maximum growth rate (threshold $\mathrm{Cd}$ concentration) and the $\mathrm{Cd}$ concentration reducing relative growth rate to $50 \%\left(\mathrm{pCd}^{50}\right)$. All treatments in which growth rates were significantly less than the control (i.e. $\mu / \mu_{\max }<1$ ), including the highest [Cd] treatment allowing maximal growth, were used in the regression.

\section{RESULTS}

\section{Cadmium toxicity}

Relative growth rates of all phytoplankton clones exhibited the same general response to increasing cadmium ion concentrations (Fig. 1). On average, growth rates were unaffected by $\mathrm{pCd}$ greater than 8.5 $\left(\mathrm{pCd}=-\log \left[\mathrm{Cd}^{2 *}\right]\right)$, but declined linearly at higher $\mathrm{Cd}^{2+}$ concentrations. Cadmium thresholds and $\mathrm{pCd}^{50} \mathrm{~s}$ were significantly correlated $\left(\mathrm{r}^{2}=0.63, \mathrm{p}<0.01\right)$, and both indices varied significantly among species (ANOVA, $\mathrm{p}<0.001$ ).

At the highest concentration of $\mathrm{Cd}$ tested ( $\mathrm{pCd} 6.85$ ), relative growth rates ranged from zero (i.e. clones did not grow in at least 3 attempts to inoculate cultures in
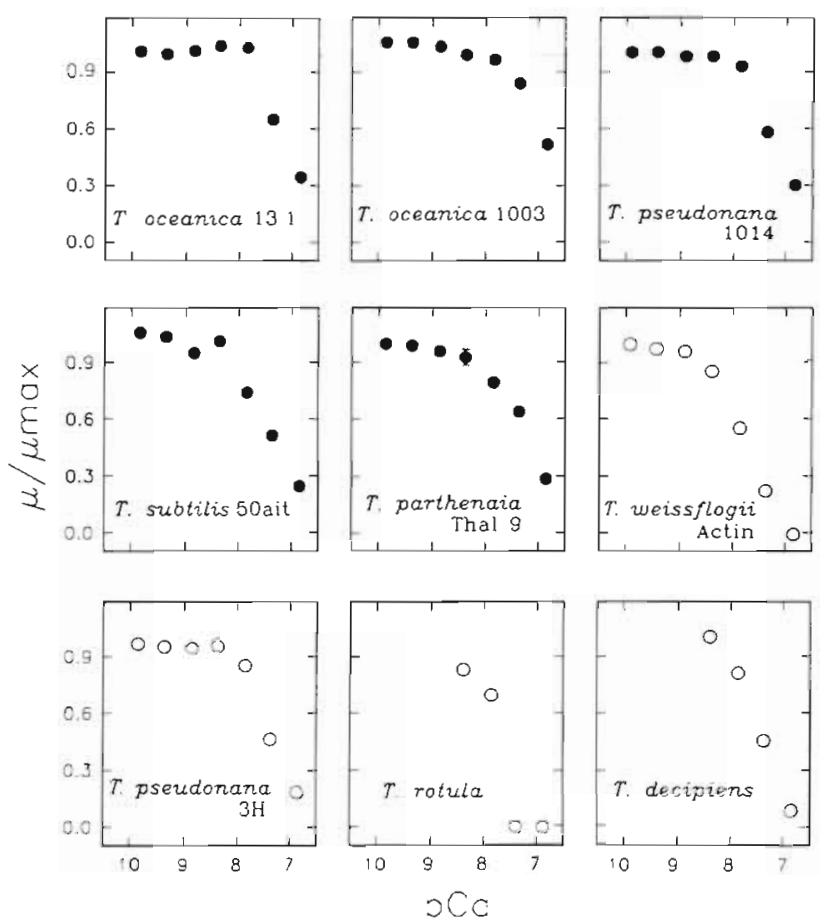

Fig. 1. Thalassiosira spp. Relative growth rates $\left(\mu / \mu_{\max }\right)$ of coastal (O) and oceanic (-) species of Thalassiosira as a function of free $\mathrm{Cd}$ ion concentration in seawater medium $\left(p C d=-\log \left[\mathrm{Cd}^{2+}\right]\right)$. Each relative growth rate is the mean of at least 6 replicates. Standard error of the mean was usually smaller than the width of the symbol the experimental medium: Thalassiosira weissflogii, $T$. rotula) to $50 \%$ (T. oceanica, clone 1003). Threshold $\mathrm{Cd}$ concentrations ranged 7 -fold from $\mathrm{pCd} 8.66$ ( $\mathrm{T}$. weissflogil) to $\mathrm{pCd} 7.80$ ( $T$. oceanica, clone 1003), while $\mathrm{pCd} \mathrm{d}^{50}$ values varied by approximately an order of magnitude $(7.86, T$. rotula; $6.76, T$. oceanica, clone 1003).

The $\mathrm{pCd}^{50} \mathrm{~s}$ of all isolates except Thalassiosira subtilis, T. parthenaia, and T. pseudonana clone 1014 were significantly different (Student-Newman-Keuls test of multiple comparisons, $p<0.01$ ) (Fig. 2). As in other studies of metāl toxicity (e.g. Gavis et al. 1981, Brand et al. 1986) the Cd sensitivities of clones isolated from trace-metal-rich coastal waters were compared to those of species indigenous to metal-deficient offshore regions. A distinct habitat-related trend was apparent in $\mathrm{pCd}^{50}$ (Fig. 2). Clones isolated from oligotrophic offshore environments [mean $\mathrm{pCd}^{50}$ (all data) $=7.09 \pm 0.19$ ] were more resistant to high external $\mathrm{Cd}$ concentrations than coastal and estuarine species [mean $\mathrm{pCd}^{50}$ (all data) $=7.64 \pm 0.24 ;$ t-test, $p<0.01]$. Cadmium thresholds also differed significantly between habitat groups although the difference was less pronounced than for $\mathrm{pCd}^{50}$ (oceanic $=8.05 \pm 0.18$, coastal $=8.37 \pm 0.26$; $t$-test, $p=0.05$ ).

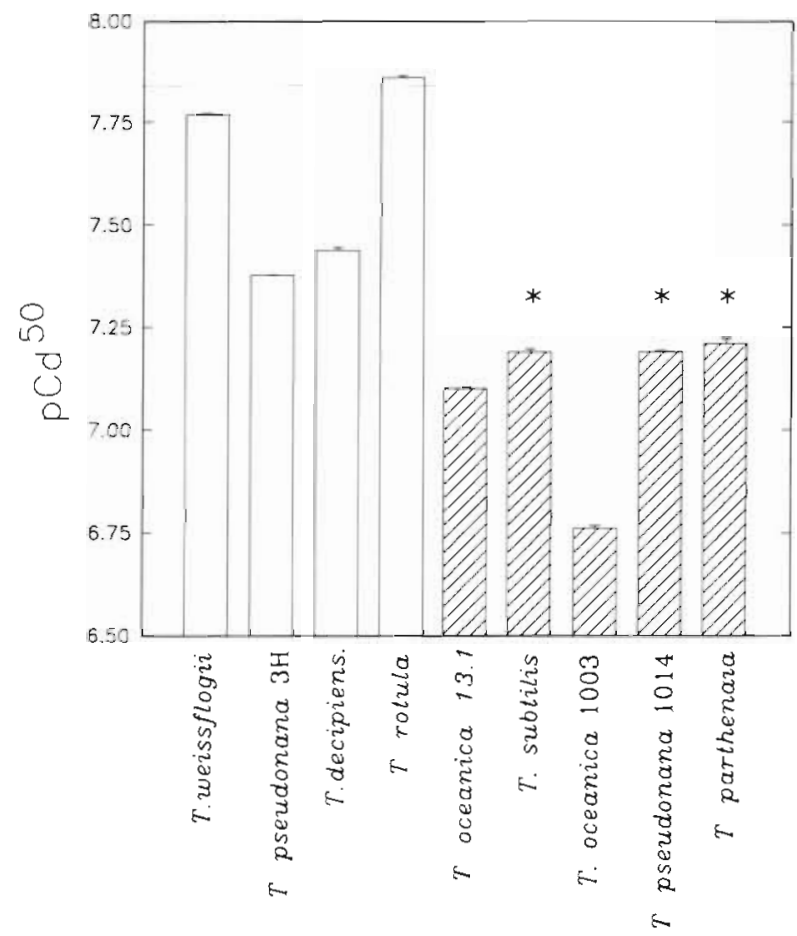

Fig 2. The extracellular free $\mathrm{Cd}^{2+}$ concentration that reduced relative growth rates of Thalassiosira spp by $50 \%\left(\mathrm{pCd}^{50}\right)$. Error bars represent $1 \mathrm{SE}$ and asterisks indicate $\mathrm{pCd}^{50} \mathrm{~s}$ that were not significantly different (ANOVA, $p>0.05$ ). Average $\mathrm{pCd}^{50} \mathrm{~s}$ of coastal (open bars) and oceanic clones (hatched bars) were significantly different (Student-Newman-Keuls test of multiple compansons, $p<0.01$ ) 
Cadmium cell quotas were measured in 2 coastal and 4 oceanic species to determine whether the greater resistance of oceanic cells could be explained by differential cellular exclusion of $\mathrm{Cd}$. In Thalassiosira oceanica clone 13.1, T. subtilis, and both clones of T. pseudonana, $\mathrm{Cd}$ quotas $(\mu \mathrm{mol} \mathrm{Cd}: \mathrm{mol} \mathrm{C})$ increased in constant proportion to extracellular $\mathrm{Cd}^{2+}$ concentrations over a pCd range of 10 to 8 . At these lower $\mathrm{Cd}^{2+}$ concentrations the slopes relating quota to dissolved $\mathrm{Cd}^{2+}$ were considerably less than $1(0.055$ to 0.33$)$, suggesting transport system regulation as opposed to passive uptake. At higher $\mathrm{Cd}^{2+}$ concentrations $(\mathrm{pCd}<8)$, Cd quotas for all species, except $T$. weissflogii, remained nearly constant despite increasing $\left[\mathrm{Cd}^{2+}\right]$, indicative of transport system saturation, feedback regulation of $\mathrm{Cd}$ uptake, and possibly efflux (Fig. 3). $T$. weissflogii showed very little change in cellular $\mathrm{Cd}$ over intermediate $\mathrm{pCd}$ values followed by a 10 -fold increase from pCd 8.5 to 7.5. At the lowest $\mathrm{Cd}^{2+}$ concentration tested ( $\mathrm{pCd}$ 9.85), Cd quotas ranged from 0.05 ( $T$. oceanica, clone 1003) to $5 \mu \mathrm{mol} \mathrm{Cd:mol} \mathrm{C}$ ( $T$. subtilis clone 50ait) and at the highest $\mathrm{Cd}^{2+}$ concentration tested ( $\mathrm{pCd}$ 6.85), T. subtilis contained approximately $100(\mu \mathrm{mol} \mathrm{Cd}: \mathrm{mol} \mathrm{C})$ while all other species contained approximately $30 \mu \mathrm{mol} \mathrm{Cd}: \mathrm{mol} \mathrm{C}$. Relative growth rates of the species showed inhibition over a

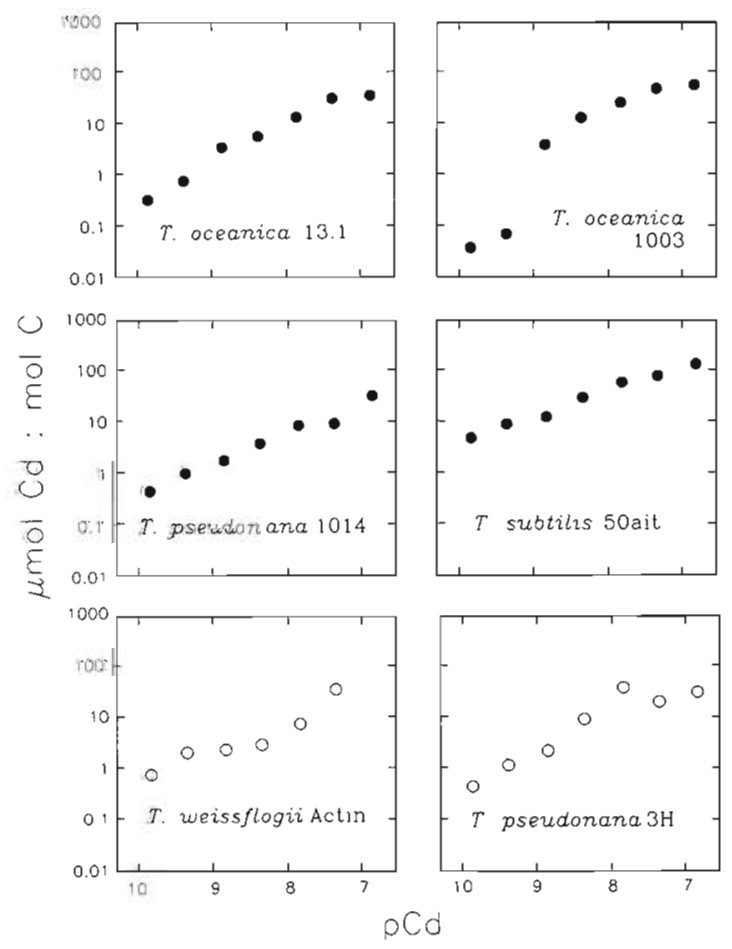

Fig. 3. Thalassiosira spp. Carbon-normalized Cd quotas $(\mu \mathrm{mol} \mathrm{Cd}: \mathrm{mol} \mathrm{C}$ ) of coastal (O) and oceanic ( $)$ species of Thalassiosira as a function of free $\mathrm{Cd}^{2+}$ ion concentrations in seawater medium. The standard error of the mean was smaller than the width of the symbol much smaller range in internal $\mathrm{Cd}$ quotas than for external concentrations (Fig. 4). Intracellular Cd concentrations reducing relative growth rates to $50 \%$ $\left(\mathrm{QCd} \mathrm{d}^{50}\right)$ were calculated as described for $\mathrm{pCd}^{50}$ values. A significant positive correlation between $\mathrm{QCd}^{50}$ and $\mathrm{pCd}^{50}$ values $\left(\mathrm{r}^{2}=0.63, \mathrm{p}=0.05\right)$ indicated that oceanic clones resistant to external $\mathrm{Cd}^{2+}$ were also more tolerant of intracellular $\mathrm{Cd}$ burdens. Thus, the greater resistance of oceanic diatoms relative to coastal species was not a consequence of greater cellular $\mathrm{Cd}$ exclusion.

\section{Zn limitation}

Coastal and oceanic species, also differed significantly in their ability to grow in culture media containing low $\mathrm{Zn}$ concentrations ( $t$-test, $\mathrm{p}=0.002$ ). At a $\mathrm{pZn}$ of 12.5 all oceanic species, with the exception of Thalassiosira pseudonana clone 1014, maintained maximum growth rates, whereas coastal species were severely $\mathrm{Zn}$-limited with growth rates ranging from 0 to $30 \%$ of $\mu_{\max }$ (control medium; $\mathrm{pZn}=10.88$ ) (Table 2). T. pseudonana clone 1014, isolated from the oceanic North Pacific gyre, was significantly $\mathrm{Zn}$ limited and grew at approximately $40 \%$ of $\mu_{\max }$

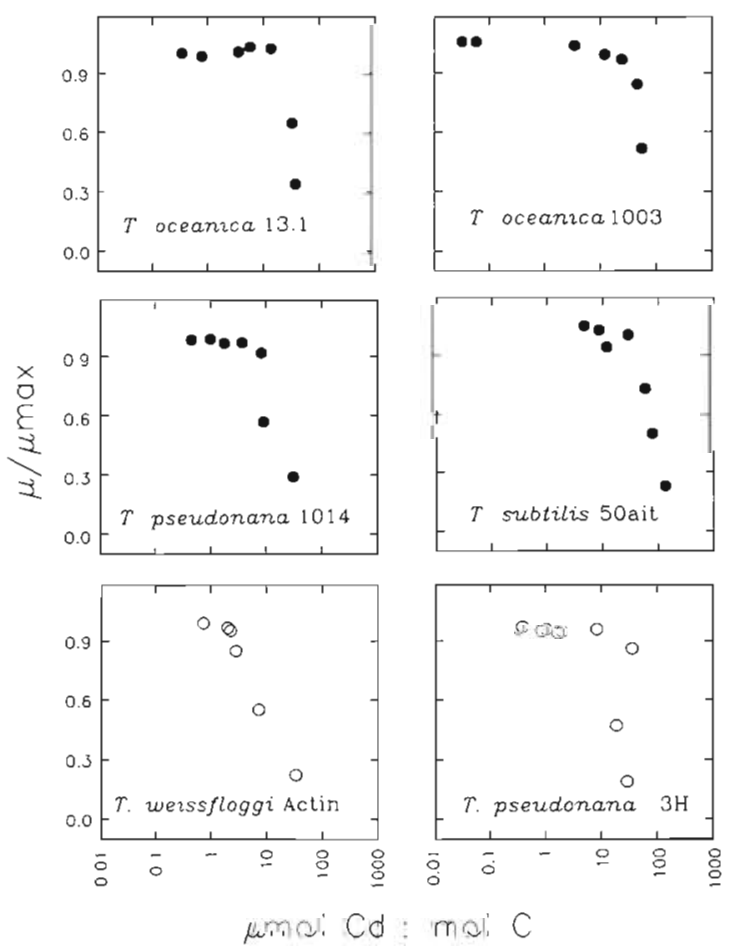

Fig. 4. Thalassiosira spp. Relative growth rates $\left(\mu / \mu_{\max }\right)$ of coastal $(0)$ and oceanic $(\bullet)$ species of Thalassiosira as a function of intracellular cadmium quotas ( $\mu \mathrm{mol} \mathrm{Cd:mol} \mathrm{C)}$. Standard error of the mean was smaller than the width of the symbol 
Table 2. Thalassiosira spp. Relative $\left(\mu / \mu_{\max }\right)$ and maximum $\left(\mu_{\max }\right)$ growth rates in $\mathrm{Zn}$-deficient culture medium ( $\mathrm{pZn} 12.5$ ). Rates are means of at least 6 replicates $\pm 1 \mathrm{SD}$

\begin{tabular}{|c|c|c|c|}
\hline Species & Habitat & $\begin{array}{c}\mu_{\max } \\
\text { (doublings } \mathrm{d}^{-1} \text { ) }\end{array}$ & $\begin{array}{c}\mu / \mu_{\max } \\
(\mathrm{pZn} 12.5)\end{array}$ \\
\hline $\begin{array}{l}\text { Thalassiosira oceanica } \\
\text { clone } 13-1\end{array}$ & Oceanic & $1.75 \pm 0.15$ & $1.0 \pm 0.088$ \\
\hline $\begin{array}{l}\text { Thalassiosira oceanica } \\
\text { clone } 1003\end{array}$ & Oceanic & $2.11 \pm 0.04$ & $1.0 \pm 0.027$ \\
\hline $\begin{array}{l}\text { Thalassiosira parthenaia } \\
\text { clone Thal } 9\end{array}$ & Oceanic & $2.11 \pm 0.08$ & $1.0 \pm 0.065$ \\
\hline $\begin{array}{l}\text { Thalassiosira pseudonana } \\
\text { clone } 1014\end{array}$ & Oceanic & $2.60 \pm 0.13$ & $0.42 \pm 0.016$ \\
\hline $\begin{array}{l}\text { Thalassiosira subtilis } \\
\text { clone 50ait }\end{array}$ & Oceanic & $1.39 \pm 0.08$ & $1.0 \pm 0.029$ \\
\hline $\begin{array}{l}\text { Thalassiosira decipiens } \\
\text { clone } 983\end{array}$ & Coastal & $1.53 \pm 0.15$ & $0.11 \pm 0.017$ \\
\hline $\begin{array}{l}\text { Thalassiosira pseudonana } \\
\text { clone } 3 \mathrm{H}\end{array}$ & Coastal & $2.72 \pm 0.15$ & $0.33 \pm 0.056$ \\
\hline $\begin{array}{l}\text { Thalassiosira rotula } \\
\text { clone } 1016\end{array}$ & Coastaì & $1.66 \pm 0.12$ & 0 \\
\hline $\begin{array}{l}\text { Thalassiosira weissflogii } \\
\text { clone Actin }\end{array}$ & Coastal & $2.07 \pm 0.11$ & $0.35 \pm 0.026$ \\
\hline
\end{tabular}

\section{$\mathrm{Cd} / \mathrm{Zn}$ interactions}

The results of $\mathrm{Cd}$ toxicity and $\mathrm{Zn}$ limitation experiments were combined to investigate $\mathrm{Cd} / \mathrm{Zn}$ interactions. Species' growth rates under Zn-limiting conditions showed a significant positive correlation with their sensitivity to extracellular $C d\left(r^{2}=0.62, p=0.012\right)$ (Fig. 5) and intracellular $\mathrm{Cd}\left(\mathrm{r}^{2}=0.76, \mathrm{p}=0.014\right)$. Oceanic isolates that were tolerant of $\mathrm{Zn}$ deficiency

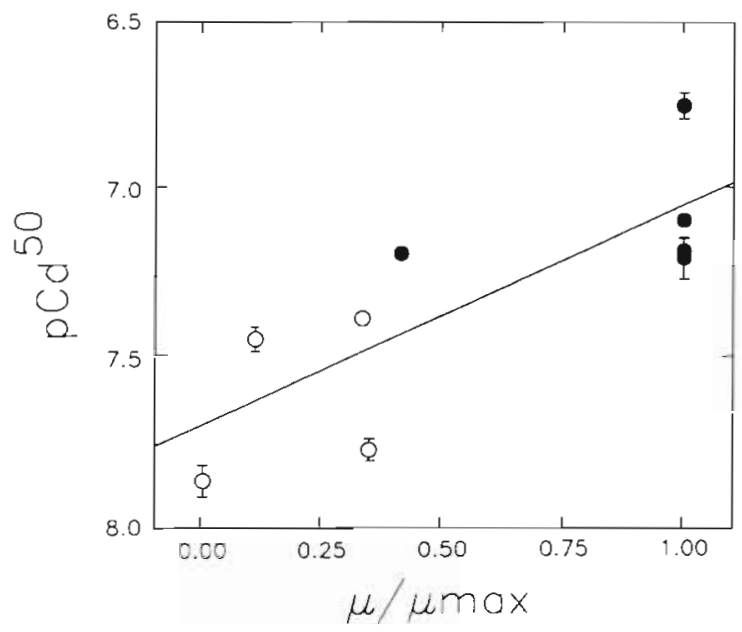

Fig. 5. Free $\mathrm{Cd}^{2+}$ ion concentrations reducing relative growth rates of coastal $(0)$ and oceanic $(\bullet)$ isolates of Thalassiosira spp. to $50 \%\left(\mathrm{pCd}^{50}\right)$ as a function of their relative growth rates $\left(\mu / \mu_{\max }\right)$ in zinc-deficient medium (pZn 12.5). Error bars represent $1 \mathrm{SE}$. The line through the data points was fit by a leastsquares procedure $\left(r^{2}=0.62, p=0.012\right)$ were more resistant to Cd than coastal species whose reproduction was severely limited both by high [Cd] and low $[\mathrm{Zn}]$. Thus, $\mathrm{Cd}$ tolerance of the phytoplankton was related to their ability to withstand $\mathrm{Zn}$ deficiency, consistent with a $\mathrm{Cd} / \mathrm{Zn}$ antagonism.

To provide experimental evidence for a $\mathrm{Cd} / \mathrm{Zn}$ antagonism, cultures of Thalassiosira weissflogii were grown under $\mathrm{Zn}$ and Fe deficiency (pZn 12.0, pFe 20.5, $100 \mu \mathrm{M}$ EDTA, all other metal activities as in Price et al. 1988/89) in the absence of added Cd at relative growth rates of approximately $60 \%$ of $\mu_{\text {max }}$ (Fig. 6). A parallel set of $\mathrm{Fe}$ - and Zn-limited cultures were enriched with a Cd concentration $(5.67 \mu \mathrm{M})$ that was not toxic to this species in metal-replete medium. Cd additions reduced the growth rates of the $\mathrm{Zn}$-limited cultures by $70 \%$ (from 1.2 to 0.38 doubling $\mathrm{d}^{-1}$ ), but had no measurable effect on the reproduction of Fe-limited cultures. Cadmium toxicity was thus specifically enhanced under $\mathrm{Zn}$-deficient conditions.

\section{DISCUSSION}

The principal finding of this study concerns the different growth responses of marine diatoms to high

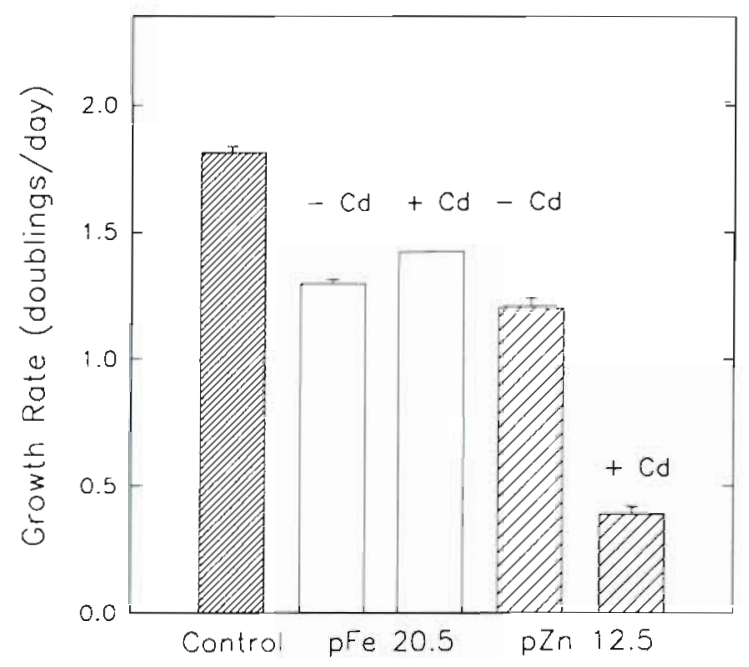

Fig. 6. Thalassiosira weissflogii. Relative growth rates of Fe-deficient ( $\mathrm{pFe} 20.5$, open bars), Zn-deficient ( $\mathrm{pZn} 12.0$, coarsely hatched bars), and control (Fe, Zn-saturated, finely hatched barj cultures of $T$. weissflogii clone Actin with and without $\mathrm{Cd}$ additions $(5.67 \mu \mathrm{M})$. Error bars represent $1 \mathrm{SE}$ 
$\mathrm{Cd}$. Threshold concentrations and $\mathrm{pCd} \mathrm{d}^{50}$ s varied considerably among the species, but were significantly lower on average for isolates derived from oceanic habitats. These species were thus more resistant to $\mathrm{Cd}$ toxicity than coastal ones which were growth-ratelimited by much lower $\mathrm{Cd}^{2+}$ concentrations (higher $\mathrm{pCd}^{50} \mathrm{~s}$ ).

\section{Cadmium quotas}

Cadmium quota measurements (Fig. 3) established that the interspecific variability in resistance was not due to $\mathrm{Cd}$ exclusion by some species. $\mathrm{QCd}^{50} \mathrm{~s}$ and $\mathrm{pCd}^{50}$ s were positively correlated to one another $\left(\mathrm{r}^{2}=\right.$ $0.63, p=0.05$ ), demonstrating that clones more resistant to high extracellular $\mathrm{Cd}$ were also more tolerant of high intracellular $\mathrm{Cd}$. The maximum quotas in all diatoms were similar and extraordinarily high (about

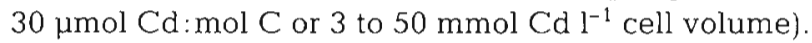
Slopes of the curves relating internal $\mathrm{Cd}$ quotas of the phytoplankton to external concentrations were also similar to one another and to those observed for other algal taxa (Ahner et al. 1995, Payne \& Price unpubl.). This correspondence among species implies that they possess similar mechanisms for regulating cellular $\mathrm{Cd}$ concentrations. Increased $\mathrm{Cd}$ resistance of oceanic diatoms compared to coastal isolates was apparently a result of their greater tolerance of high cellular burdens.

One possible explanation for the greater tolerance may be differences between the cellular distribution and function of $\mathrm{Cd}$ among the isolates. Relative partitioning of $\mathrm{Cd}$ between high and low molecular weight biochemicals of the cytosol depends on the absolute amount of $\mathrm{Cd}$ and the presence of other metals (Price \& Morel 1990). Systematic variations in the relative concentrations of these pools and hence in the proportions of reactive and non-reactive $\mathrm{Cd}$ might easily account for the habitat pattern observed. The available evidence, however, does not strongly support this explanation.

Detoxification of Cd occurs through the biosynthesis of small, metal-complexing phytochelatins (Gekeler et al. 1988), but oceanic and neritic species produce similar amounts of these peptides in response to Cd stress (Ahner et al. 1995). A greater capacity for Cd detoxification in oceanic species thus seems unlikely. Cadmium may also play a beneficial role for phytoplankton by substituting for $\mathrm{Zn}$ in certain cellular functions (Price \& Morel 1990). Because oceanic species have evolved in habitats where essential metals are scarce, they might be hypothesized to be more adept in making such substitutions. If so, then $\mathrm{Cd}$ would be less deleterious to their growth compared to coastal species. Although neither of these explanations can be entirely ruled out, as discussed below, the habitat related pattern in $\mathrm{Cd}$ tolerance most likely reflects the greater ability of oceanic clones to tolerate essential metal deficiency.

Deficiency and toxicity of trace metals are not necessarily independent phenomena. Low concentrations of essential metals, for example, can amplify the deleterious effects of toxicants, as in the case of $\mathrm{Cd}$ and $\mathrm{Zn}$ (Lee et al. 1995). Cellular receptor ligands of phytoplankton exhibit similar coordination properties and so are unable to completely discriminate among cationic trace metals (Sunda 1988/89). Indeed, competitive inhibition of uptake is reported for a number of trace metals such as Cu and Mn (Sunda \& Huntsman 1983), $\mathrm{Cu}$ and $\mathrm{Zn}$ (Rueter \& Morel 1981), and $\mathrm{Cu}$ and Fe (Murphy et al. 1984). These antagonistic and substitutive reactions may be detrimental to cellular physiology, because they displace essential metals from their characteristic biochemical coordination sites. Such interference with transport and or assimilation may create toxic effects that ultimately result from a deficiency of an essential metal. Species that endure metal deficiency would thus be predicted to be more resistant to the high concentrations of $\mathrm{Cd}$.

\section{Cadmium/zinc interactions}

Support for such an essential and toxic metal interaction was provided by examining the relationship between $\mathrm{Cd}$-stressed and $\mathrm{Zn}$-deficient growth rates. In low $\mathrm{Zn}$ medium, oceanic species maintained maximal rates of growth as expected (Sunda \& Huntsman 1992), but coastal species were severely rate-limited. Both $\mathrm{pCd}^{50} \mathrm{~s}$ and $\mathrm{QCd}^{50} \mathrm{~s}$ were positively correlated to growth rates in low $\mathrm{Zn}$ so that phytoplankton most resistant to $\mathrm{Cd}$ toxicity were those least affected by $\mathrm{Zn}$ limitation. Oceanic species with low metal requirements thus appear to be less sensitive to elevated $\mathrm{Cd}$ concentrations than coastal species.

This correlative relationship by itself cannot be interpreted mechanistically as resulting from a specific $\mathrm{Cd} / \mathrm{Zn}$ antagonism. Phytoplankton that grow well in medium containing low $\mathrm{Zn}$ are also able to tolerate low concentrations of other essential metals. Relative growth rates of $\mathrm{Fe}$ - and $\mathrm{Zn}$-limited phytoplankton are indeed positively correlated $\left(\mathrm{r}^{2}=0.75, \mathrm{p}<0.05\right.$; data adapted from Brand et al. 1983). Any one of these elements could be equally important in explaining the species variability in $\mathrm{Cd}$ toxicity.

More direct evidence of the specific nature of the Cd-essential metal interaction was provided by the metal-limitation/threshold experiment. This experiment was designed to discriminate between $\mathrm{Cd}$ and $\mathrm{Fe}$ 
or Cd and Zn antagonisms by measuring growth of one of the diatom species with various combinations of these metals. Because potential competitive interactions between toxic and essential metals are exacerbated when the essential ones are growth-rate-limiting (e.g. $\mathrm{Cu} / \mathrm{Zn}$, Rueter \& Morel 1981; Cd/Zn, Lee et al. 1995), the concentrations of $\mathrm{Fe}$ and $\mathrm{Zn}$ were lowered in the media.

One of the first studies of metal antagonisms documented a $\mathrm{Cd}$ and $\mathrm{Mn}$ transport competition in Chlorella pyrenoidosa (Hart et al. 1979). Such an antagonism cannot be entirely ruled out in the present study, but for some of the most Cd-intolerant diatoms we were unable to induce $\mathrm{Mn}$ limitation even when Mn was completely omitted from the media. The lack of effect of low Mn in Thalassiosira weissflogii was not a result of $\mathrm{Mn}$ contamination of our base media, because we were easily able to limit $T$. pseudonana of $\mathrm{Mn}$ using the same medium (N. M. Zador \& N M. Price unpubl.). At least in the test species, $T$. weissflogii, Cd growth toxicity was unlikely to be caused by an antagonism with $\mathrm{Mn}$.

A Cd concentration that had no effect on metalreplete cultures became clearly toxic to Zn-limited Thalassiosira weissflogii, reducing its growth rate to $30 \%$ of $\mu_{\max }$. This enhanced toxicity did not result from a general stress imposed on cells by essential metal deficiency because cells that were Fe-limited to the same extent were completely unaffected by the same $\mathrm{Cd}$ additions. Thus, $\mathrm{Cd}$ levels that were not toxic under Zn-saturating conditions became severely inhibitory when $\mathrm{Zn}$ concentrations were low, providing strong evidence of a specific $\mathrm{Cd} / \mathrm{Zn}_{\mathrm{n}}$ interaction.

Although the growth rate antagonism between $\mathrm{Cd} / \mathrm{Zn}$ was only experimentally demonstrated under $\mathrm{Zn}$-limiting conditions, it is a plausible explanation for the pattern of $\mathrm{Cd}$ tolerance occurring in Zn-replete medium (Fig. 2). Harrison \& Morel (1983) previously showed that a $\mathrm{Cd}$ and $\mathrm{Fe}$ antagonistic interaction in Fe-deficient Thalassiosira weissflogii also existed when Fe levels were 100 -fold higher, so such extrapolation is not without foundation. Establishing which $\mathrm{Cd}$ essential metal antagonism occurs in metal-replete medium will ultimately provide an unambigous test of the $\mathrm{Cd} / \mathrm{Zn}$ hypothesis.

\section{Habitat-related patterns in Cd toxicity}

The habitat-dependent pattern in Cd toxicity that is evident from our results has not been reported before. In a comprehensive study that examined 20 phytoplankton species from 17 genera and 4 classes Brand et al. (1986) observed significant phylogenetic differences in $\mathrm{Cd}$ tolerance, but no significant trends be- tween coastal and oceanic isolates. Closer inspection of their data (Table 6, p 245), however, revealed that within every taxonomic class, oceanic phytoplankton had lower $\mathrm{pCd}^{50}$ s (i.e. were more resistant) than neritic isolates. The lack of significant habitat-related patterns in Cd sensitivity (Brand et al. 1986) may have resulted from the qualitative, categorical habitat classification scheme that is in general use.

Phytoplankton are classified as either 'coastal' or 'oceanic' based on the geographic distance of their collection sites from the continental boundary (Ryther \& Kramer 1961). Although terrestrial influences are known to differentiate coastal waters from the open sea, a dichotomous classification scheme does not reflect the spatial variability within coastal and oceanic zones or the continuity with which biological and chemical characteristics vary between these habitats. This classification fails to account for a number of important hydrographic phenomena, such as oceanic upwelling and island effects, that can result in the emergence of persistent, local sub-habitats. To circumvent these difficulties, it is necessary to replace discrete habitat categories with a continuous, quantitative variable. Given that trace metal concentrations decrease by several orders of magnitude along coastal to oceanic transects (Bruland 1980, Bruland \& Franks 1983) and that the ability of phytoplankton to tolerate essential metal-limiting conditions is an evolutionary stable trait closely reflecting the availability of these micronutrients in their natural habitats (Brand et al 1983. Sunda \& Huntsman 1992, Sunda et al. 1991), we propose that species' relative growth rates under essential trace metal deficiency can be used as such a variable.

'Coastal' and 'oceanic' phytoplankton can be distinguished by their relative growth rates under low zinc concentrations ( $p Z n$ 12.5), although considerable variation exists within each group (Table 2). At low $\mathrm{Zn}^{2+}$ concentrations, coastal species grew very slowly whereas all but one oceanic species maintained maximum growth rates. This exceptional oceanic species, Thalassiosira pseudonana, exemplifies the limitations of the traditional habitat classification scheme. The clone (1014) was isolated from the 'oceanic', central north Pacific gyre, an oligotrophic region characterized by low concentrations of nutrients compared to typical coastal waters. Its relative growth rate at $\mathrm{pZn}$ 12.5 was $42 \%$ of $\mu_{\max }$, the lowest among species in the 'oceanic' group, but highest among species in the 'coastal' group.

To further validate the use of the quantitative habitat classification scheme, Cd toxicity data of Brand et al. (1986) were reanalyzed, replacing discrete habitat classifications with the relative growth rates of the same species under Zn-limiting conditions (Brand et 


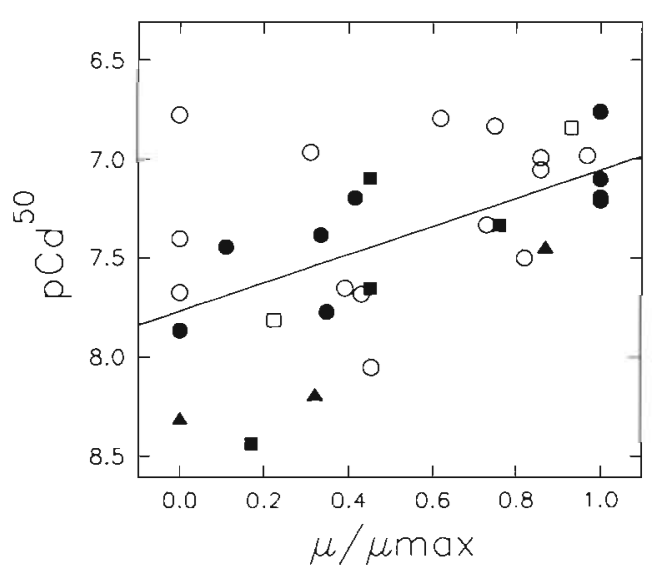

Fig. 7. Cadmium sensitivity $\left(\mathrm{pCd}^{50}\right)$ of a number of phytoplankton taxa as a function of their relative growth rates in Zn-deficient culture medium. The data are taken from this study, Brand et al. (1983, 1986), and Payne \& Price (unpubl.). (-) Thalassiosira spp., this study; (O) other diatoms; ( $\bullet$ dinoflagellates; ( coccolithophorids; $(\square)$ green algae $\left(\mathrm{I}^{2}=0.30\right.$,

$$
\mathrm{n}=32, \mathrm{p}=0.001 \text { ) }
$$

al. 1983). Data from a variety of other phytoplankton were also included in the analysis (Payne \& Price unpubl.). A significant correlation $(p=0.001)$ was observed between $\mathrm{Cd}$ tolerance and $\mathrm{Zn}$-limited growth rates (Fig. 7), suggesting that indeed a 'habitat'-related pattern exists among a diversity of phytoplankton taxa and that the species least affected by essential metal limitation, such as $\mathrm{Zn}$, are those most resistant to $\mathrm{Cd}$ toxicity. As is apparent from the scatter of the plot, other ecological and physiological factors are also important in determining $\mathrm{Cd}$ resistance among diverse phytoplankton taxa.

Acknowledgements. We thank Chris Payne for the Cd sensitivity data and Maria Maldonado for comments. This work was supported by the Natural Sciences and Engineering Research Council of Canada and by a McGill University Faculty of Graduate Studies and Research Equipment Grant.

\section{LITERATURE CITED}

Ahner BA, Kong S, Morel FMM (1995) Phytochelatin production in marine algae: 1 . An interspecific comparison. Limnol Oceanogr 40:649-657

Ahner BA, Price NM, Morel FMM (1994) Phytochelatin production by marine phytoplankton at low free metal ion concentrations: laboratory studies and field data from Massachusetts Bay. Proc Nat Acad Sci USA 91. 8433-8436

Brand LE, Guillard RRL, Murphy LS (1981) A method for the rapid and precise determination of acclimated phytoplankton reproductive rates. J Plankton Res 3:193-201

Brand LE, Sunda WG, Guillard RRL (1983) Limitation of marine phytoplankton reproductive rates by zinc, manganese, and iron. Limnol Oceanogr 28:1182-1198
Brand LE, Sunda WG, Guillard RRL (1986) Reduction of marine phytoplankton reproduction rates by copper and cadmium. J Exp Mar Biol Ecol 96:225-250

Bruland KW (1980) Oceanographic distributions of cadmium, zinc, nickel, and copper in the North Pacific. Earth Planet Sci Lett 47:176-198

Bruland KW (1992) Complexation of cadmium by natural organic ligands in the central North Pacific. Limnol Oceanogr 37:1008-1017

Bruland KW, Franks RP (1983) Mn, Ni, Cu, Zn, and Cd in the western north Atlantic. In: Wong CS, Boyle EA, Bruland KW, Burton JD, Goldberg ED (eds) Trace metals in the ocean. Proceedings of NATO Advanced Research Institute. Plenum Press, New York, p 395-414

Davies AG (1978) Pollution studies with marine plankton. Part II. Heavy metals. Adv Mar Biol 15:381-508

Fisher NS, Bohé M, Teyssié JL (1984) Accumulation and toxicity of $\mathrm{Cd}, \mathrm{Zn}, \mathrm{Ag}$, and $\mathrm{Hg}$ in four marine phytoplankters. Mar Ecol Prog Ser 18:201-213

Foster PL, Morel FMM (1982) Reversal of cadmium toxicity in a diatom: an interaction between cadmium toxicity and iron. Limnol Oceanogr 27:745-752

Gavis J, Guillard RRL, Woodward BL (1981) Cupric ion activity and the growth of clones isolated from different marine environments. J Mar Res 39:315-333

Gekeler W, Grill E, Winnacker EL, Zenk MH (1988) Algae sequester heavy metals via synthesis of phytochelatin complexes. Arch Microbiol 150:197-202

Harrison GI. Morel FMM (1983) Antagonism between cadmium and iron in the marine diatom Thalassiosira weissflogii. J Phycol 19:495-507

Hart BA, Bertram PE, Scaife BD (1979) Cadmium transport by Chlorella pyrenoidosa. Environ Res 18:327-335

Jensen A, Rystad G, Melsom S (1974) Heavy metal tolerance of marine phytoplankton. I. The tolerance of three algal species to zinc in coastal waters. J Exp Mar Biol Ecol $15: 145-157$

Keller MD, Bellows WK, Guillard RRL (1988) Microwave treatment for sterilization of phytoplankton culture media. J Exp Mar Biol Ecol 117:279-283

Lee JG, Morel FMM (1995) Replacement of zinc by cadmium in marine phytoplankton. Mar Ecol Prog Ser 127:305-309

Lee JG, Roberts SB, Morel FMM (1995) Cadmium: a nutrient for the marine diatom. Thalassiosira weissflogii. Limnol Oceanogr 40:1056-1063

Martin JH and others (1994) Testing the iron hypothesis in ecosystems of the equatorial Pacific Ocean. Nature 376: $123-129$

Martin JM, Whitfield M (1983) The significance of the river input of chemical elements to the ocean. In: Wong CS, Boyle EA, Bruland KW, Burton JD, Goldberg ED (eds) Trace metals in the ocean. Proceedings of NATO Advanced Research Institute. Plenum Press, New York, p 475-508

Murphy LS, Guillard RRL, Brown JF (1984) The effects of iron and manganese on copper sensitivity in diatoms: differences in the response of closely related neritic and oceanic species. Biol Oceanogr 3:187-201

Price NM, Ahner BA, Morel FMM (1994) The equatorial Pacific Ocean: grazer controlled populations in an ironlimited ecosystem. Limnol Oceanogr 39:520-534

Price NM, Andersen LF, Morel FMM (1991) Iron and nitrogen nutrition of equatorial Pacific plankton. Deep Sea Res 38: $1361-1378$

Price NM, Harrison GI, Hering JG, Hudson RJ, Nirel PMV, Palenik B, Morel FMM (1988/89) Preparation and chemistry of the artificial algal culture medium Aquil. Biol Oceanogr 6:443-461 
Price NM, Morel FMM (1990) Cadmium and cobalt substitution for zinc in a marine diatom. Nature 344:658-660

Price NM, Morel FMM (1994) Trace metal nutrition and toxicity in phytoplankton. In: Rai LC, Gaur JP, Soeder CJ (eds) Algae and water pollution (Advances in limnology; Heft 42) E. Schweizerbart'sche Verlagsbuchhandlung. Stuttgart, p 79-97

Rueter JG, Morel FMM (1981) The interaction between zinc deficiency and copper toxicity as it affects the silicic acid uptake mechanisms of Thalassiosira pseudonana. Limnol Oceanogr 26:67-73

Ryther JH, Kramer DD (1961) Relative iron requirement of some coastal and offshore plankton algae. Ecology 42 : $444-446$

Sunda WG (1988/89) Trace metal interactions with phytoplankton. Biol Oceanogr 6:411-442

Sunda WG, Barber RT, Huntsman, SA (1981) Phytoplankton growth in nutrient rich seawater: importance of

This article was submitted to the editor copper-manganese cellular interactions. J Mar Res 39 $567-586$

Sunda WG, Huntsman SA (1983) Effect of competitive interactions between manganese and copper on cellular manganese and growth in estuarine and oceanic species of the diatom Thalassiosira. Limnol Oceanogr 28:924-934

Sunda WG, Huntsman SA (1992) Mutual feedback interactions between zinc and phytoplankton in seawater. Limnol Oceanogr $37: 25-41$

Sunda WG, Swift DG, Huntsman SA (1991) Low iron requirement for growth in oceanic phytoplankton. Nature 351 $55-57$

Westall JC, Zachary JL, Morel, FMM (1976) MINEQL: a computer program for the calculation of chemical equilibrium composition of aqueous systems. Tech. Note No. 18. RM Parsons Lab for Water Resources and Environmental Engineering. MIT, Dept of Civil Engineering Cambridge, MA

Manuscript first received: January 1,1995 Revised version accepted: March 8, 1996 